\title{
Comparison of Forest Fire Profiles in Londrina, Brazil and Pisa, Italy
}

\author{
João Francisco Labres dos Santos ${ }^{1}$ (D), Alexandre França Tetto ${ }^{1}$ (D), \\ Andrea Bertacchi $^{2}$ (D), Antonio Carlos Batista ${ }^{1}$ (D), Ronaldo Viana Soares ${ }^{1}$ \\ ${ }^{1}$ Universidade Federal do Paraná - UFPR, Curitiba/PR, Brasil \\ ${ }^{2}$ Universitadegli Studi di Pisa Dipartimentodi Scienze Agrarie Alimentari e Agro-ambientali, Pisa/TO, Itália
}

\begin{abstract}
The main aim of this study was to compare the historical profile of forest fires and to elaborate a risk zoning map for the regions of Londrina, Brazil, and Pisa, Italy in the period from 2005 to 2014. The records of fire occurrences were correlated with days of rain and temperature in the study areas. The results showed that 1,435 and 629 fires were recorded in the analyzed period, affecting areas of 3,220.4 and 1,550.8 ha in the regions of Londrina and Pisa, respectively. Data were then spaced in a risk zoning map. Fire occurrences and precipitation presented inverse correlation of 0.76 and 0.81 for Londrina and Pisa, respectively. Temperature showed direct correlation of 0.82 with fire occurrences for Pisa, and inverse correlation of 0.56 for Londrina. The analyzed data may serve as subside for planning fire prevention and combat activities.
\end{abstract}

Keywords: precipitation, temperature, fire risk zoning, risk. 


\section{INTRODUCTION}

Forest fires dramatically transform ecosystems. Several factors are related to the occurrence of fires and climate elements are among them, which have a decisive influence on start and propagation of fire (Fimia, 2009). Understanding the historical behavior of precipitation associated with historical information on various aspects regarding the origin and behavior of fires are important for developing forest fire control plans. This offers opportunities to visualize different prevention scenarios (Cabán, 2009).

According to Myers (2006), every single ecosystem on Earth potentially has a fire regime, a history that has in some way affected the structure and composition of species. Seasonal changes in weather conditions also influence the moisture content of live and dead fuel materials (Lara, 2009). Therefore, precipitation distribution is critical for the start, duration and end of most hazardous fire seasons (Soares \& Batista, 2007).

According to Nunes et al. (2009), precipitation is a limiting factor in both fire ignition and propagation, and there is strong correlation between the occurrence of large fires and prolonged drought periods. In a recent study, Liu \& Wimberly (2015) reported that precipitation has greater influence on the occurrence of fires compared to temperature and humidity. Sampaio et al. (2006) found that the region of Londrina presents precipitation near zero in the months of July and August. Similar behavior was reported by Stefanini (2008) for the region of Pisa.

Due to the importance of understanding statistical information regarding fire occurrences over time for the elaboration of prevention and fire control plans and in order to help compare profiles, the hypothesis that precipitation has preponderant influence in different regions of the planet was tested.

The aim of this study was to compare the profiles of forest fires and the influence of precipitation on fire occurrences in Londrina, mid-northern region of the state of Paraná, Brazil, and in the province of Pisa, Tuscany, Italy, as well as to develop a risk zoning map for both regions.

\section{MATERIAL AND METHODS}

\subsection{Study area characterization}

Two areas were selected to perform this study:

a) Four cities of the Metropolitan Region of Londrina, state of Paraná, Brazil, as follows: Londrina, Arapongas, Cambé and Rolândia, totaling an area of $2,989.18 \mathrm{~km}^{2}$, located between coordinates $23^{\circ} 01^{\prime}$ and $23^{\circ} 56^{\prime}$ south latitude and $50^{\circ} 52^{\prime}$ and $51^{\circ} 35^{\prime}$ west longitude (Instituto Brasileiro de Geografia e Estatística - IBGE, 2015). According to the Köppen classification, the region presents Cfa climate characterized as temperate with year-round rainfall and hot summer, with temperatures above $22^{\circ} \mathrm{C}$ in the warmer months and mean temperature in the coldest months higher than or equal to $-3^{\circ} \mathrm{C}$ (Soares et al., 2015), as shown in Figure 1B. Originally covered by Semi-deciduous Seasonal Forest, this area is conditioned to a period of low rainfall, causing the upper canopy of trees to lose their leaves (Roderjan et al., 2002). According to Hardesty et al. (2005), this is a fire-sensitive ecosystem;

b) The province of Pisa, Tuscany, Italy, with $2,444.72 \mathrm{~km}^{2}$ located at coordinates $43^{\circ} 43^{\prime}$ north latitude and $10^{\circ} 25^{\prime}$ east longitude (Istituto Nazionale di Statistica- ISTAT, 2015), is in Csa climate region according to the Köppen classification, seasoned with hot and dry summers, maximum temperatures above $22^{\circ} \mathrm{C}$, and temperatures below $-3^{\circ} \mathrm{C}$ in the colder months (Kottek et al., 2006) (Figure 1A). The vegetation of the region is basically composed of coniferous and broadleaf forests, in which the latter are divided into two large systems: deciduous broadleaf trees, which lose their leaves in winter and are not very drought resistant; and perennial xerophilic sclerophytes, which maintain their leaves in winter. Another form of vegetation very common but mainly present on the coast is "macchia mediterranea", generally formed by perennial shrubs, which are resistant to dry climate (Regione Toscana, 1998). It is a fire-dependent ecosystem (Hardesty et al., 2005).

\subsection{Methodological process}

Fire database was provided by the Fire Department of the state of Paraná (Comando do Corpo de Bombeiros- CCB), through the SysBM-CCB, and by the Servizio Antincendi Boschivi (AIB) of the Province 
of Pisa, Italy. Temperature and precipitation data were provided by the Instituto Nacional de Meteorologia (INMET) and Servizio Agrometeorologico Regione Toscana (ARSIA). All data refer to the period from
$01 / 01 / 2005$ to $12 / 31 / 2014$, totaling 10 years of observation. Data processing was performed with the help of Microsoft Excel 2016 and the Statgraphics Centurion XV software.
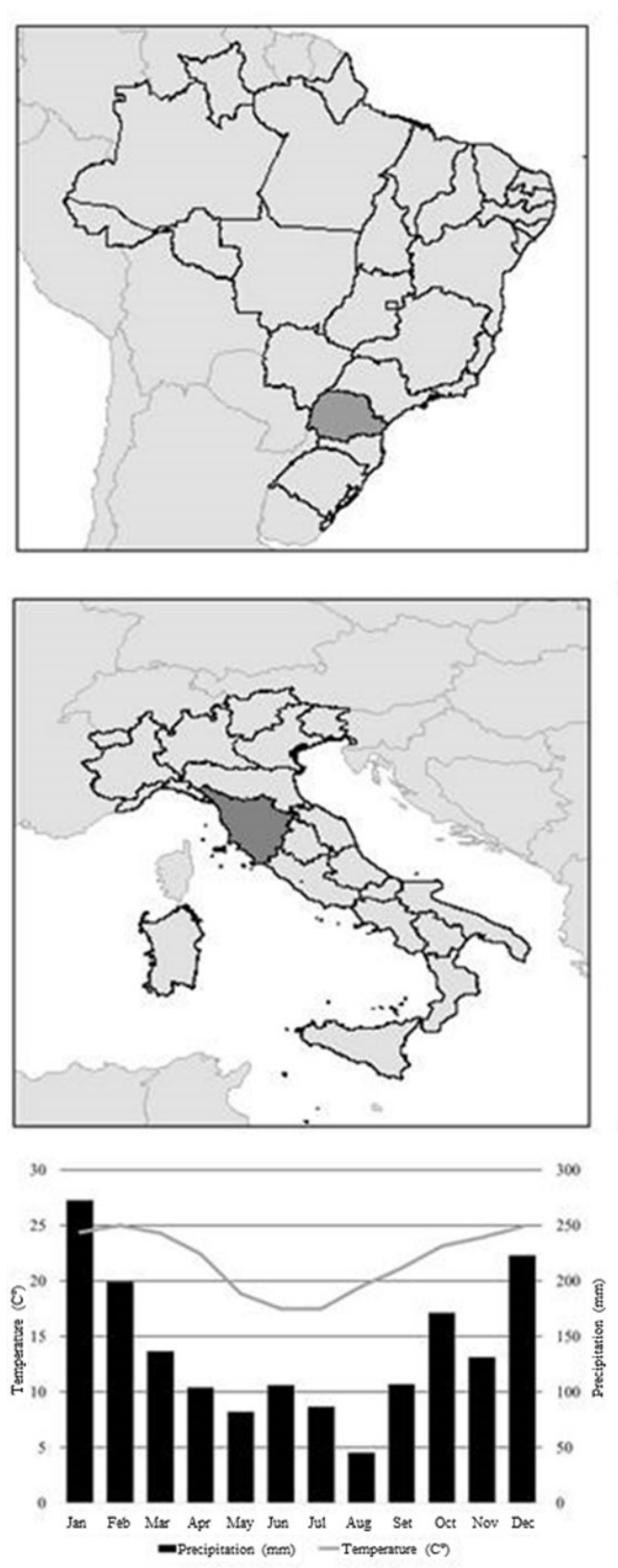
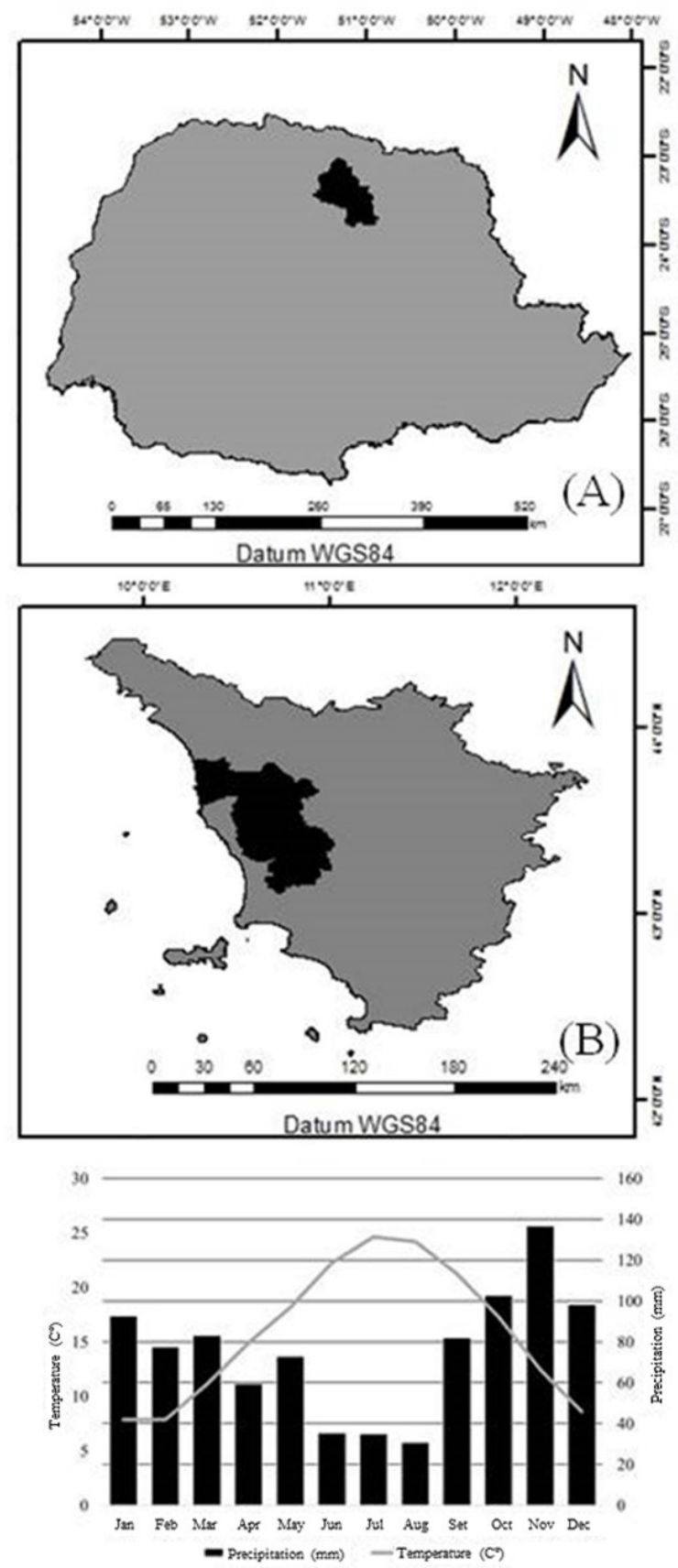

(B)

Figure 1. Study areas and climographs of Londrina (A) and Pisa (B) in the period from 2005 to 2014. Sources: IBGE (2015) and ISTAT (2015); Instituto Nacional de Meteorologia (INMET, 2015) and Servizio Agrometeorologico Regione Toscana (ARSIA, 2015, prepared by the authors (2017). 
Comparison of profiles followed some methodological elements recommended by Rodríguez (1999) and Tetto et al. (2012). Temporal analysis was carried out considering the following variables: fire occurrence and burnt area related to year and month, and further relating them to rainy days and temperature for the period. Rainy days with rainfall that accumulated precipitation above $2.4 \mathrm{~mm}$ were considered (Soares, 1972).

The zoning map was developed according to methodology applied by Bovio \& Camia (1997), in which 10 square kilometer areas are delimited in cities and the obtained historical data are standardized and distributed into Basic Units (BUs). Each basic unit represents a city of the analyzed regions. To better spatialize and interpret occurrences in the chosen period, six variables were determined based on the frequency of fires and the affected area, namely: number of fires/BU/10 km²/year; number of fires > 30 ha; percentage of years with fire (\%); mean burned area by one fire occurrence (ha); median of the burned area by one fire (ha); maximum burned area by one fire (ha).

Subsequently, BUs were distributed into classes through cluster analysis using the Ward (1963) method. Determining the number of classes for each region was based on the fusion coefficient of the Euclidean distances of each sample, respecting the limit of five risk levels (null, low, medium, high and very high) (Bovio \& Camia, 1997) with the aid of the Statgraphics Centurion XV software. Based on analyzed variables, spacing was performed using the ARCGIS 10.3 software (Figure 2).
Evaluating variable cause was not possible for none of the regions, since it is not included in the Fire Department System of Paraná, as firemen do not have attributes for such, as established in Article 45 of the State of Paraná Constitution (Paraná, 2006). The situation is similar in the province of Pisa, in which the Nuclei Investigativi Provinciali di Polizia Ambientale e Forestale (NICAF) of the Corpo Forestale dello Stato are responsible for the investigation (Corpo Forestale dello Stato, 2015), while the Servizio Antincendi Boschivi is responsible for monitoring, prevention and forecasting, according to article 3 of law 353 from November 21, 2000 (Italia, 2000).

\section{RESULTS AND DISCUSSION}

\subsection{Number of fire occurrences and affected areas}

From 2005 to 2014 , 1,435 fire occurrences were observed in Londrina, which affected 3,220.4 hectares. During the same period, 629 fire occurrences were observed in Pisa, which affected 1,550.8 hectares (Table 1).

The average frequency of fire records in Londrina and Pisa was 143.5 and 62.9 fires per year, respectively. The highest values were observed from 2005 to 2008 and between 2010 and 2012 in Londrina, and 2011 and 2012 in Pisa. The lack of a well-defined public policy for awareness in the use of controlled fires in agriculture contributes to the high number of occurrences

DATA

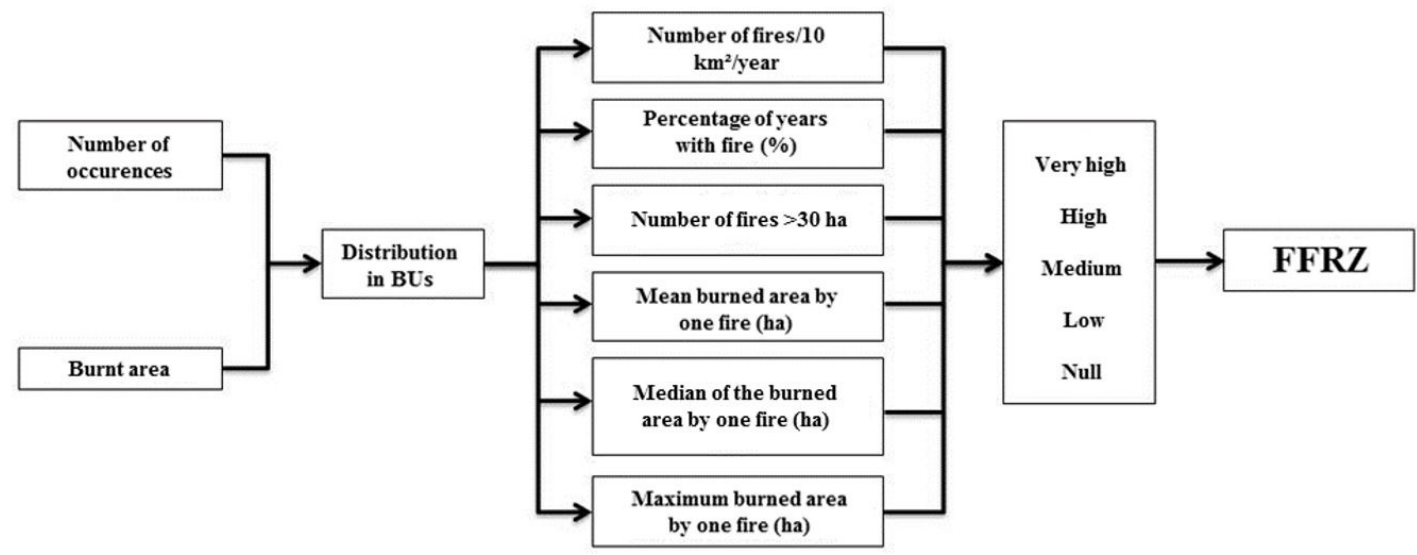

Figure 2. Composition of forest fire risk zoning (FFRZ). Source: prepared by the authors (2017). 
Table 1. Forest fire occurrences in Londrina and Pisa in the period from 2005 to 2014.

\begin{tabular}{|c|c|c|c|c|c|c|c|c|c|c|}
\hline \multirow{3}{*}{ Year } & \multicolumn{5}{|c|}{ Londrina } & \multicolumn{5}{|c|}{ Pisa } \\
\hline & \multicolumn{2}{|c|}{ Fire occurrences } & \multicolumn{2}{|c|}{ Area } & \multirow{2}{*}{$\frac{\text { Mean }}{\text { (ha/fire) }}$} & \multicolumn{2}{|c|}{ Fire occurrences } & \multicolumn{2}{|c|}{ Area } & \multirow{2}{*}{$\frac{\text { Mean }}{\text { (ha/fire) }}$} \\
\hline & $n^{0}$ & $\%$ & ha & $\%$ & & $n^{0}$ & $\%$ & ha & $\%$ & \\
\hline 2005 & 174 & 12.13 & 31.0 & 0.96 & 0.18 & 48 & 7.63 & 92.6 & 5.97 & 1.93 \\
\hline 2006 & 218 & 15.19 & 2486.9 & 77.22 & 11.41 & 58 & 9.22 & 61.6 & 3.97 & 1.06 \\
\hline 2007 & 211 & 14.70 & 181.6 & 5.64 & 0.86 & 69 & 10.97 & 52.6 & 3.39 & 0.76 \\
\hline 2008 & 135 & 9.41 & 63.3 & 1.97 & 0.47 & 54 & 8.59 & 85.1 & 5.49 & 1.58 \\
\hline 2009 & 65 & 4.53 & 58.7 & 1.82 & 0.90 & 75 & 11.92 & 642.8 & 41.45 & 8.57 \\
\hline 2010 & 150 & 10.45 & 124.7 & 3.87 & 0.83 & 28 & 4.45 & 10.8 & 0.69 & 0.38 \\
\hline 2011 & 186 & 12.96 & 143.0 & 4.44 & 0.77 & 114 & 18.12 & 201.7 & 13.01 & 1.77 \\
\hline 2012 & 115 & 8.01 & 54.2 & 1.68 & 0.47 & 123 & 19.55 & 352.9 & 22.76 & 2.87 \\
\hline 2013 & 98 & 6.83 & 47.7 & 1.48 & 0.49 & 44 & 7.00 & 39.7 & 2.56 & 0.90 \\
\hline 2014 & 83 & 5.78 & 29.2 & 0.91 & 0.35 & 16 & 2.54 & 10.9 & 0.71 & 0.68 \\
\hline Total & 1435 & 100.00 & 3220.4 & 100.00 & - & 629 & 100.00 & 1550.8 & 100.00 & - \\
\hline Mean & 143.5 & - & 322.0 & - & 1.67 & 62.9 & - & 155.1 & - & 2.05 \\
\hline
\end{tabular}

Source: CCB (2015) and AIB (2015), prepared by the authors (2017).

in Londrina (Vosgerau et al., 2006). The burning of vegetable waste for agriculture purposes follows specific norms in Tuscany, which carries out trainings and campaigns for the population, especially for farmers who use this practice. This along with determined risk zones based on the history of the region allow rationalizing resources for prevention, and are factors that contribute to reduce number of fire occurrences (Regione Toscana, 2014).

The annual mean burned areas in Londrina and Pisa were 322.0 and 155.1 ha, respectively, with emphasis on years 2006 in Londrina and 2009 in Pisa for burned hectares. The mean of the burned areas for Londrina and Pisa were 1.67 and 2.05 hectares per fire, respectively, highlighting the years 2006 for Londrina and 2009 for Pisa, with the highest number of hectares burned per occurrence. These values are higher than those found by Rodríguez et al. (2013) for Brazil and Cuba.

It was observed that August presented an average of 2.8 rainy days for Londrina (Figure $3 \mathrm{~A}$ ) and 2.7 days for Pisa (Figure 3C). Average temperatures showed different behavior, with months of June and July being the coldest for Londrina, and June to August as the hottest months for Pisa, which is explained by their location in different hemispheres.

This precipitation behavior caused an increase in the number of fire occurrences and affected areas. For Londrina, $47.52 \%$ of forest fires occurred during the period from July to September, and $90.93 \%$ of areas were also affected in this period (Figure 3B). In Pisa, $67.57 \%$ of forest fires with $83.09 \%$ of areas affected occurred in the same period (Figure 3D).

In this study, greater correlation was observed between number of fire occurrences and rainy days $(r=-0.76$ for Londrina and $r=-0.81$ for Pisa). For the region of Londrina, smaller inverse correlation of $56 \%$ was observed between number of fire occurrences and temperature. On the other hand, direct correlation of $82 \%$ was found between days with fire occurrences and temperature for Pisa. As evidenced by Torres et al. (2011), rainfall distribution and fire occurrences show inverse relationship for both areas and when associated with high temperatures, as observed in Pisa, it is better correlated with fire occurrences.

According to Liu \& Wimberly (2015), climatic elements have weak influence on the size of forest fires. This can be observed in the region of Londrina, where the burned area presented low inverse correlation with rainy days $(r=-0.50)$ and temperature $(r=-0.28)$. However, correlation of $\mathrm{r}=-0.68$ was observed between burned area and precipitation in Pisa, and $\mathrm{r}=0.70$ when related to temperature, showing that these variables, especially temperature, influence fire propagation.

\subsection{Historical zoning}

Historical variables were grouped into 5 fire risk levels for the region of Pisa, while Londrina has 2 risk levels, both at high risk of fire. Table 2 shows the mean values for historical class for each region. 
For the region of Pisa, Class 2 presented irregular distribution in the occurrences of fires due to the low number of years with fires (10\%) and the number of forest fires per basic unit.

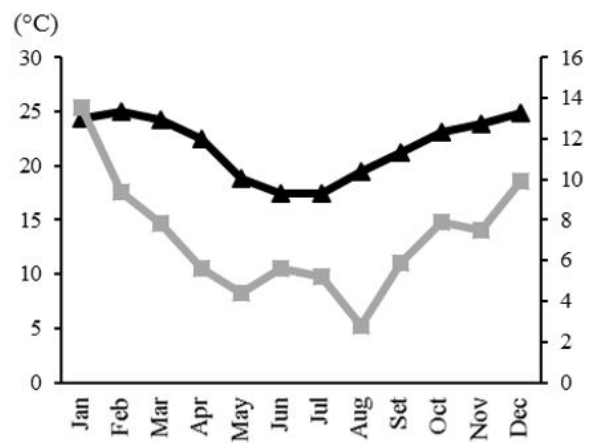

(A)

$$
\begin{aligned}
& \longrightarrow \text { Temperature }\left(\mathrm{C}^{\circ}\right) \\
& =\text { Days with rain }
\end{aligned}
$$

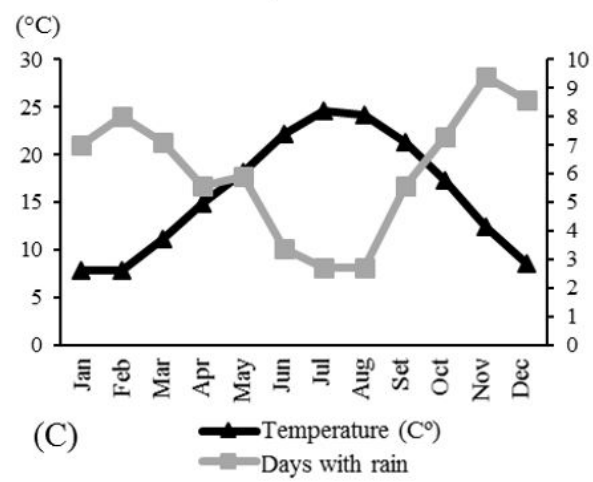

Class 3 presented the highest number of cities and mean and median values of burned areas, as well as for the maximum burned area. This situation did not occur in Londrina, which presented classes with high
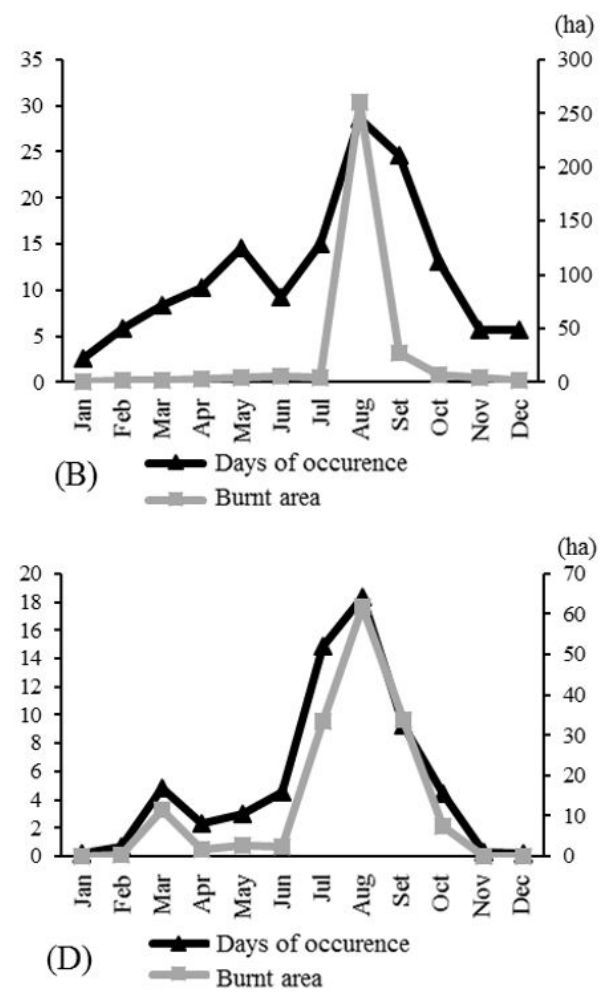

Figure 3. Rainfall distribution, temperature, fire occurrence and burned areas per month in Londrina (A and B) and Pisa (C and D) in the period from 2005 to 2015. Sources: INMET (2015), ARSIA, (2015), CCB (2015) and AIB (2015), prepared by the authors (2016).

Table 2. Fire occurrence variables calculated for Londrina and Pisa.

\begin{tabular}{|c|c|c|c|c|c|c|c|c|c|c|c|c|c|c|}
\hline & \multirow[t]{2}{*}{$\begin{array}{c}\text { No. of } \\
\text { BUs }\end{array}$} & \multirow[t]{2}{*}{ Classes } & \multicolumn{2}{|c|}{$\begin{array}{c}\text { Number of } \\
\text { fires/BU/ } \\
10 \mathrm{~km}^{2} / \text { year }\end{array}$} & \multicolumn{2}{|c|}{$\begin{array}{l}\text { Number of } \\
\text { fires }>30 \text { ha }\end{array}$} & \multicolumn{2}{|c|}{$\begin{array}{c}\text { Percentage } \\
\text { of years with } \\
\text { forest fires } \\
(\%)\end{array}$} & \multicolumn{2}{|c|}{$\begin{array}{c}\text { Mean } \\
\text { burned area } \\
\text { in one fire } \\
\text { occurrence } \\
\text { (ha) }\end{array}$} & \multicolumn{2}{|c|}{$\begin{array}{l}\text { Median of } \\
\text { the burned } \\
\text { area in } \\
\text { one fire } \\
\text { occurrence } \\
\text { (ha) }\end{array}$} & \multicolumn{2}{|c|}{$\begin{array}{l}\text { Maximum } \\
\text { burned area } \\
\text { in one fire } \\
\text { occurrence } \\
\text { (ha) }\end{array}$} \\
\hline & & & Mean & $s^{2}$ & Mean & $s^{2}$ & Mean & $s^{2}$ & Mean & $s^{2}$ & Mean & $s^{2}$ & Mean & $s^{2}$ \\
\hline \multirow{2}{*}{ } & 3 & 4 & 0.74 & 0.81 & 0 & 0 & 100 & 0 & 0.77 & 0.56 & 0.11 & 0.16 & 30.7 & 15.14 \\
\hline & 1 & 5 & 0.58 & & 3 & & 100 & & 11.26 & & 0.05 & & 2400 & \\
\hline \multirow{5}{*}{$\frac{\mathscr{B}}{2}$} & 1 & 1 & 0 & & 0 & & 0 & & 0 & & 0 & & 0 & \\
\hline & 1 & 2 & 0.09 & & 0 & & 10 & & 7 & & 7 & & 7 & \\
\hline & 27 & 3 & 0.22 & 0.17 & 0 & 0 & 52 & 25.62 & 1.37 & 1.17 & 0.37 & 0.55 & 10.1 & 14.03 \\
\hline & 3 & 4 & 1.45 & 0.4 & 0 & 0 & 100 & 0 & 0.37 & 0.55 & 0.05 & 0.38 & 18.7 & 15.96 \\
\hline & 4 & 5 & 0.37 & 0.43 & 1 & 0 & 60 & 0 & 10.04 & 14.03 & 0.38 & 1.74 & 123.3 & 0.49 \\
\hline
\end{tabular}

Sources: CCB (2015) and AIB (2015), prepared by the authors (2017). Note: Number of BUs: number of provinces/municipalities in Londrina and Pisa according to risk classes. Classes: 1 (null), 2 (low), 3 (medium), 4 (high) and 5 (very high). 
means of burned area and maximum area burned per fire occurrence.

Class 5 represented cities that historically have high risk of fire; both Pisa and Londrina are similar due to the high number of maximum burnt areas (123.3 and $2400 \mathrm{ha}$ ). It was observed that only one fire occurrence with $>30$ ha of burned area occurred in Pisa, while three occurred in Londrina.

The region of Londrina presented the two highest fire risk levels (Figure 4), which was due to the large extensions of basic units and probably to the use of fire in agriculture. Basic unit that makes up class 5 represents very high fire risk level due to the occurrence of fires throughout the period and the maximum area burned by a single fire was 2400.0 ha. While carrying out a risk zoning map according to demographic density, Batista et al. (2014) verified that the region of Cambé was within the highest risk class.
Four basic units were grouped in Pisa with mean burned area (10.04 ha) similar to that found for class 5 in Londrina (11.26 ha) (Figure 5).

The presence of Pisan Mountains in the city of Calci contributes to frequent fire occurrences (Di Renzo et al., 2012), configuring it as a region of very high fire risk. The same occurs with Bientina and Santa Maria a Monte, which comprise the area of the Montefalcone State Nature Reserve, where Cerbaia hills are located (Lisa et al., 2015). Another important factor in these areas is the prevalence of "macchie sclerofille sempreverdi" (Mediterranean vegetation of evergreen sclerophylls) often mixed with easily ignitable Pinus pinaster L. (Pinaceae) species (Bertacchi et al., 2004), which leads to the occurrence of severe fires with high propagation rates (Viedma et al., 2015). The central belt extending from Pisa to Pomarance has medium risk level, which may be related to the existence of pasture areas and

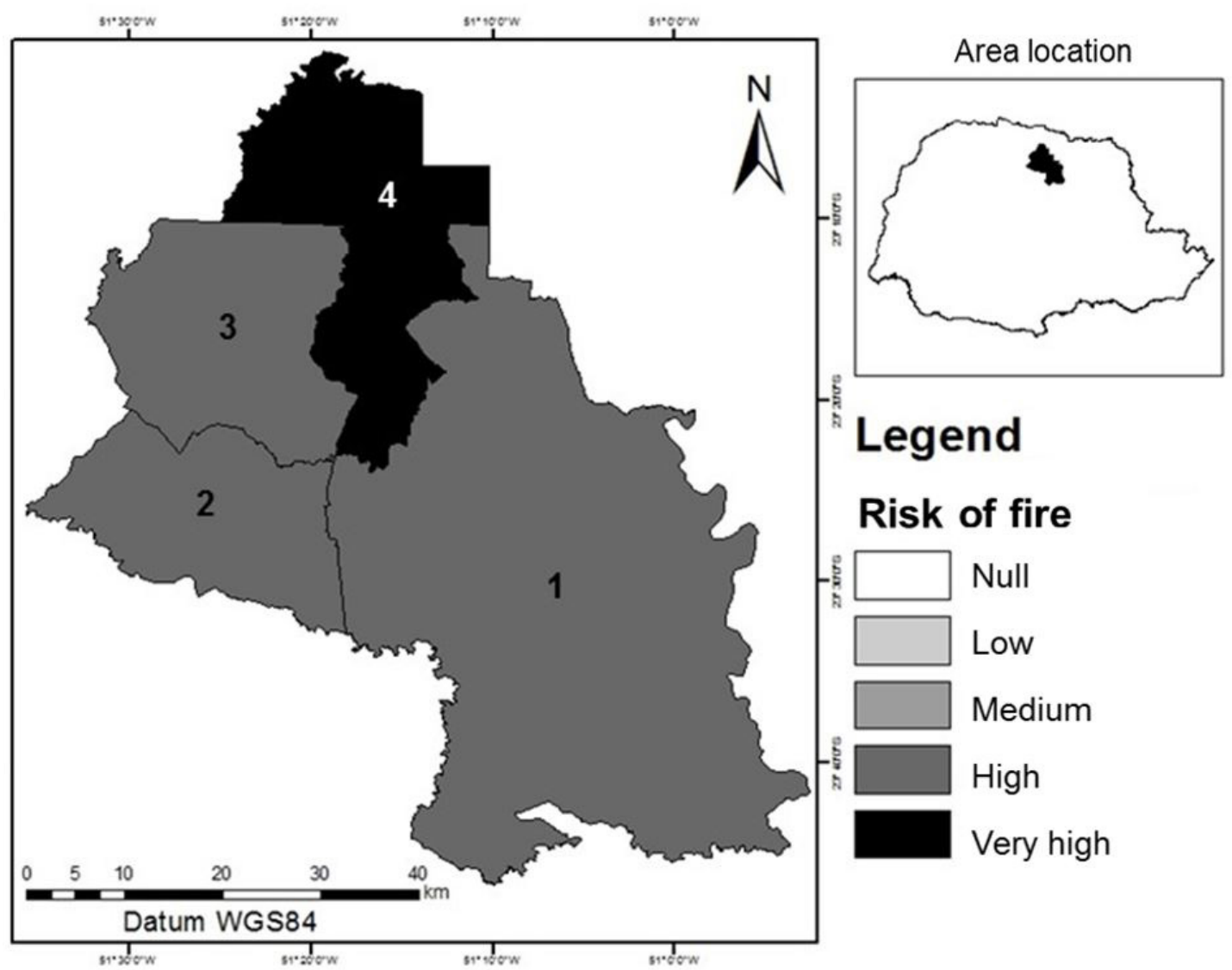

Figure 4. Historical risk zoning for Londrina in the period from 2005 to 2014. Sources: IBGE (2015) and CCB (2015), prepared by the authors (2016). Note: 1 (Londrina), 2 (Arapongas), 3 (Rolândia) and 4 (Cambé). 


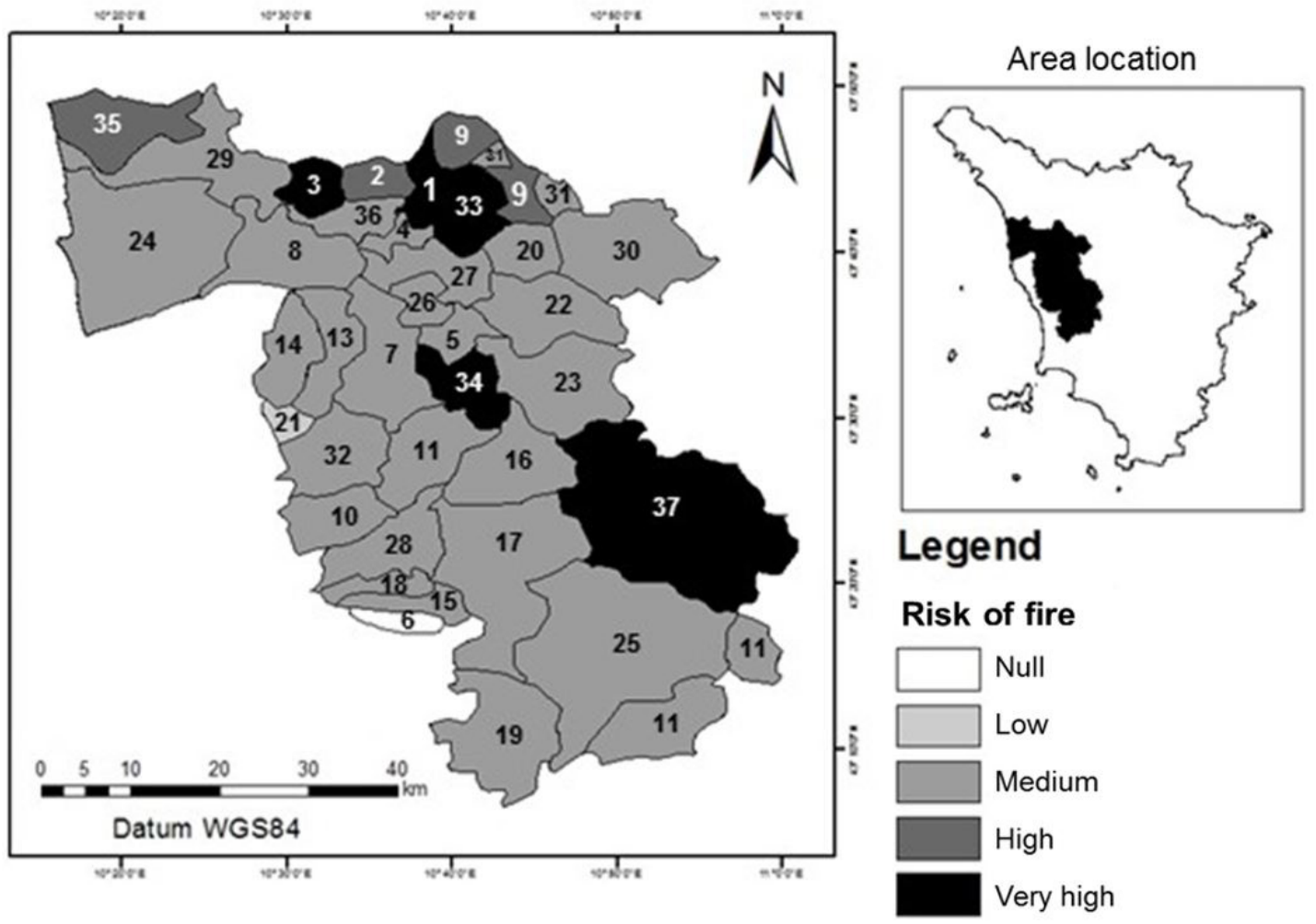

Figure 5. Historical risk zoning for Pisa in the period from 2005 to 2015. Sources: ISTAT (2015) and AIB (2015), prepared by the authors (2016). Note: 1 (Bientina), 2 (Buti), 3 (Calci), 4 (Calcinaia), 5 (Capannoli), 6 (Casale Marittimo), 7 (CascianaTerme - Lari), 8 (Cascina), 9 (Castelfranco Di Sotto), 10 (CastellinaMarittima), 11 (Castelnuovo Di Val Di Cecina), 12 (Chianni), 13 (Crespina - Lorenzana), 14 (Fauglia), 15 (Guardistallo), 16 (Lajatico), 17 (Montecatini Val diCecina), 18 (Montescudaio), 19 (MonteverdiMarittimo), 20 (Montopoli In Val D’arno), 21 (OrcianoPisano), 22 (Palaia), 23 (Peccioli), 24 (Pisa), 25 (Pomarance), 26(Ponsacco), 27 (Pontedera), 28 (Riparbella), 29 (San Giuliano Terme), 30 (San Miniato), 31 (Santa Croce Sull'arno), 32 (Santa Luce), 33(Santa Maria a Monte), 34 (Terriciolla), 35 (Vecchiano), 36 (Vicopisano) and 37(Volterra).

the use of fire to clear the land (Lovreglio et al., 2012). The provinces of Vecchiano, Terricciolaand Volterra were grouped into the high and very high risk classes, which is different from what is observed in practice, and this difference was due to the occurrence of large fires during the period. Such information opens the possibility for further investigations. The city of Casale Marittimo was the only with no records of fire occurrences during the study period; therefore, it corresponds to null risk level.

\section{CONCLUSIONS}

The hypothesis that precipitation is a preponderant factor in distinct regions has shown to be partially true for both study areas. i) Precipitation was a predominant factor for the occurrence of fires in Londrina; however, better correlation was observed in Pisa when the dry season was associated with elevated temperatures;

ii) It was possible to compare the historical profile of forest fires in both regions according to the number of occurrences, burnt area, temperature and precipitation;

iii) Londrina presented higher fire risk as evidenced by the zoning with higher risk classes, while the Pisa region had distribution with greater number of cities within moderate risk class.

\section{ACKNOWLEDGEMENTS}

To CAPES (Coordenação de Aperfeiçoamento de Pessoal de Nível Superior) for funding this research. The authors would also like to thank UFPR (Universidade 
Federal do Paraná) and UNIPI (Università di Pisa), for their support in carrying out this work, also the Fire Department of the state of Paraná (Comando do Corpo de Bombeiros - CCB) and the Servizio Antincendi Boschivi (AIB) of the Province of Pisa, for providing the database.

\section{SUBMISSION STATUS}

Received: 29 nov., 2016

Accepted: 12 mar., 2018

\section{CORRESPONDENCE TO}

\section{João Francisco Labres dos Santos}

Divisão de Ciências Agrárias, Universidade Federal do Paraná - UFPR, Av. Pref. Lothário Meissner, 900, CEP 80210-170, Curitiba, PR, Brasil

e-mail: joflabres@yahoo.com.br

\section{REFERENCES}

Batista AC, Tetto AF, Deppe F, Grodziki L, Grassi JT. Análise dos impactos das mudanças climáticas sobre o risco de incêndios florestais no estado do Paraná. Scientia Forestalis 2014; 42(104): 491-501.

Bertacchi A, Sani A, Tomei PE. La vegetazione del Monte Pisano. Pisa: Felice; 2004.

Bovio G, Camia A. Land zoning based on fire history. International Journal of Wildland Fire 1997; 7(3): 249-258. http://dx.doi.org/10.1071/WF9970249.

Cabán AG. Planificación y análisis para la defensa contra incêndios forestales. In: Vélez R, editor. La defensa contra incendios forestales: fundamentos y experiências. Madrid: McGraw-Hill; 2009.

Comando do Corpo de Bombeiros - CCB. SysBM-CCB: Cascavel [online]. 2015 [cited 2015 June 14]. Available from: http://www.bombeiroscascavel.com.br/registroccb/

Corpo Forestale dello Stato. Organizzazione per la Tutela Forestale, Ambientale e Agroalimentare [online]. 2015 [cited 2015 May 8]. Available from: http://www.carabinieri.it/ arma/oggi/organizzazione/organizzazione-per-la-tutelaforestale-ambientale-e-agroalimentare

Di Renzo F, Fratini R, Marchi E. Stima dei danni da incendi sui Monti Pisani. Sherwood 2012; (187): 9-14.

Fimia JCM. Fatores meteorológicos. In: Vélez R, editor. La defensa contra incendiosforestales: fundamentos $y$ experiências. Madrid: McGraw-Hill; 2009.
Hardesty J, Myers RL, Fulks W. Fire, ecosystems, and people: a preliminary assessment of fire as a global conservation issue. The George Wright Forum 2005; 22(4): 78-87.

Instituto Brasileiro de Geografia e Estatística - IBGE. Brasil/Paraná/Londrina [online]. 2015 [cited 2015 May 15]. Available from: http://cidades.ibge.gov.br/xtras/perfil. php? $\operatorname{codmun}=411370$

Instituto Nacional de Meteorologia - INMET. BDMEP - Banco de Dados Meteorológicos para Ensino e Pesquisa [online]. 2015 [cited 2015 May 7]. Available from: http:// www.inmet.gov.br/portal/index.php?r=bdmep/bdmep

Istituto Nazionale Di Statistica - ISTAT. Superfici Delle Unità Amministrative a fini statistici. La superficie dei Comuni, delle Province e delle Regioni italiane al 9 ottobre 2011 [online]. 2015 [cited 2015 May 7]. Available from: http://www.istat.it/it/archivio/82599

Italia. Ministero Dell'Ambiente. Della Tutela del Territorio e del Mare. Legge-quadro in materiadi incendi boschivi, 30 de novembro de 2000. Gazzetta Ufficiale, Roma, LZ (2000).

Kottek M, Grieser J, Beck C, Rudolf B, Rubel F. World map of the Köppen-Geiger climate classification updated. MeteorologischeZeitschrift 2006; 15(3): 259-263. http:// dx.doi.org/10.1127/0941-2948/2006/0130.

Lara $\mathrm{CH}$. El concepto de inflamabilidad. In: Vélez R, editor. La defensa contra incendiosforestales: fundamentos y experiências. Madrid: McGraw-Hill; 2009.

Lisa C, Paffetti D, Nocentini S, Marchi E, Bottalico F, Fiorentini $S$ et al. Impact of wildfire on the edaphic microarthropod community in a Pinus pinaster forest in central Italy. IForest (Viterbo) 2015; 8(6): 874-883. http:// dx.doi.org/10.3832/ifor1404-008.

Liu Z, Wimberly MC. Climatic and landscape influences on fire regimes from 1984 to 2010 in the Western United States. PLoS One 2015; 10(10): 1-20. PMid:26465959.

Lovreglio R, Marciano A, Patrone A, Leone V. Le motivazionidegli incendi boschivi in Italia: risultatiprel iminaridiun'indagine pilota nelle Province a maggiorei ncidenzadi incendi. Forest 2012; 9(1): 137-147. http:// dx.doi.org/10.3832/efor0693-009.

Myers RL. Convivendo com o fogo: manutenção dos ecossistemas \& subsistência com o manejo integrado do fogo. Tallahassee: The Nature Conservancy; 2006.

Nunes JRS, Batista AC, Soares RV, Fier ISN, Santos CC. Climatologia do comportamento da precipitação no Distrito Florestal de Monte Alegre, PR, Brasil. Floresta 2009; 39(4): 783-792. http://dx.doi.org/10.5380/rf.v39i4.16313.

Paraná. Constituição do Estado 1989. Curitiba: Imprensa Oficial; 2006

Regione Toscana. La vegetazione forestale. Florença: Edizioni Regione Toscana; 1998.

Regione Toscana. Piano operativo AIB 2014-2016 (art. 74 L.R. 39/00). Pistoia: Tipografica Pistoeise; 2014 
Roderjan CV, Galvão F, Kunyioshi YS, Hatschbach GG. Unidades fitogeográficas do estado do Paraná, Brasil. Ciência \& Ambiente 2002; (24): 75-92.

Rodríguez MPR, Soares RV, Batista AC, Tetto AF, Becerra LWM. Comparação entre o Perfil dos Incêndios Florestais de Monte Alegre, Brasil, e de Pinar Del Río, Cuba. Floresta 2013; 43(2): 231-240. http://dx.doi.org/10.5380/ rf.v43i2.27650.

Rodríguez MPR. Bases metodológicas para el perfeccionamiento de la prevención de los incendios forestales [tese] Pinar del Río: Universidad de Pinar delRío; 1999.

Sampaio SC, Longo AJ, Queiroz MMF, Gomes BM, Vilas Boas MA, Suszek M. Estimativa e distribuição da precipitação provável no estado do Paraná. Acta Scientiarum: Human and Social Sciences 2006; 28(2): 267-272.

Servizio Agrometeorologico - ARSIA. Regione Toscana [online]. 2015 [cited 2015 May 6]. Available from: http:// agrometeo.arsia.toscana.it/

Servizio Antincendi Boschivi - AIB. Consorzio Lamma [online]. 2015 [cited 2015 May 14]. Available from: http:// www.lamma.rete.toscana.it/aib/frameset.html

Soares RV, Batista AC, Tetto AF. Meteorologia e climatologia florestal. Curitiba: FUPEF; 2015.

Soares RV, Batista AC. Incêndios florestais: controle, efeitos e uso do fogo. Curitiba: FUPEF; 2007.

Soares RV. Determinação de um índice de perigo de incêndio para a região centro-paranaense, Brasil [dissertação].
Turrialba: Centro Agronomico Tropical de Enseanza e Investigacion; 1972.

Stefanini MC. Analisi dendrocronologiche su esemplari dell'Orto Botanico di Pisa. Attidella Società Toscana de Scienze Naturalidi Pisa 2008; 115(1): 99-105.

Tetto AF, Batista AC, Soares RV. Ocorrência de incêndios florestais no estado do Paraná, no período de 2005 a 2010. Floresta 2012; 42(2): 391-398. http://dx.doi.org/10.5380/ rf.v42i2.22516.

Torres FTP, Ribeiro GA, Martins SV, Lima GS. Correlações entre os elementos meteorológicos e as ocorrências de incêndios florestais na área urbana de Juiz de Fora, MG. Revista Árvore 2011; 35(1): 143-150. http://dx.doi. org/10.1590/S0100-67622011000100017.

Viedma O, Quesada J, Torres I, De Santis A, Moreno JM. Fire severity in a large fire in a Pinus pinaster forest is highly predictable from burning conditions. Ecosystem 2015; 18(2): 233-250. http://dx.doi.org/10.1007/s10021014-9824-y.

Vosgerau JL, Batista AC, Soares RV, Grodzki L. Avaliação dos registros de incêndios florestais do estado do Paraná no período de 1991 a 2001. Floresta 2006; 36(1): 23-32. http://dx.doi.org/10.5380/rf.v36i1.5608.

Ward JH Jr. Hierarchical grouping to optimize an objective function. Journal of the American Statistical Association 1963; 58(301): 236-244. http://dx.doi.org/10.1080/0162 1459.1963 .10500845 . 